\title{
Does ontogeny modulate irradiance-elicited plasticity of leaf traits in saplings of rain-forest tree species? A test with Dicorynia guianensis and Tachigali melinonii (Fabaceae, Caesalpinioideae)
}

\author{
Sabrina Coste ${ }^{1}$, Jean-Christophe RoGGY ${ }^{1}$, Laurianne GARRAUD ${ }^{1}$, Patrick HeURET ${ }^{2}$, Eric NiCOLINI ${ }^{3}$, \\ Erwin DREYER ${ }^{4,5 *}$ \\ ${ }^{1}$ AgroParisTech-ENGREF, INRA, UMR CIRAD-ENGREF-INRA-CNRS “Écologie des Forêts de Guyane ”, \\ Campus Agronomique de Kourou, 97387 Kourou, Guyane, France \\ ${ }^{2}$ INRA, UMR AMAP“ Botanique et Bioinformatique de l'Architecture des Plantes ”, TA A51/PS2 34398 Montpellier Cedex 5, France \\ ${ }^{3}$ CIRAD, UMR AMAP “ Botanique et Bioinformatique des plantes ", F97310, Kourou, Guyane, France \\ ${ }^{4}$ INRA, UMR 1137 " Écologie et Écophysiologie Forestières ", 54280 Champenoux, France \\ ${ }^{5}$ Nancy-Université, UMR 1137 “Écologie et Écophysiologie Forestières ”, 54500 Vandœuvre, France
}

(Received 18 September 2008; revised version 30 January 2009; accepted 9 March 2009)

Keywords:

plant architecture /

phenotypic plasticity /

photosynthetic capacity /

leaf structure /

tropical rain forest

\begin{abstract}
- Irradiance elicits a large plasticity in leaf traits, but little is known about the modulation of this plasticity by ontogeny. Interactive effects of relative irradiance and ontogeny were assessed on leaf traits for two tropical rainforest tree species: Dicorynia guianensis Amshoff and Tachigali melinonii (Harms) Barneby (Fabaceae, Caesalpinioideae).

- Eleven morphological and physiological leaf traits, relative to photosynthetic performance, were measured on saplings at three different architectural development stages (ASD 1,2 and 3) and used to derive composite traits like photosynthetic $\mathrm{N}$-use efficiency. Measurements were made along a natural irradiance gradient.

- The effect of $A S D$ was very visible and differed between the two species. For Dicorynia guianensis, only leaf mass-per-area (LMA) significantly increased with ASDs whereas for Tachigali melinonii, almost all traits were affected by $A S D$ : $L M A$, leaf $\mathrm{N}$ content and photosynthetic capacity increased from $A S D 1$ to $A S D$ 3. Photosynthetic N-use-efficiency was not affected by ASD in any species.

- Leaf traits were severely modulated by irradiance, whereas the degree of plasticity was very similar among $A S D$ s. Only few interactions were detected between irradiance and $A S D$, for leaf thickness, carbon content, and the ratio $\mathrm{Chl} / \mathrm{N}$ in T. melinonii and for photosynthetic capacity in D. guianensis. - We conclude that ontogenic development and irradiance-elicited plasticity modulated leaf traits, with almost no interaction, i.e., the degree of irradiance-elicited plasticity was stable across development stages and independent of ontogeny in these two species, at least in the early stages of development assessed here.
\end{abstract}

Résumé - L'ontogenèse module-t-elle la plasticité des traits foliaires induite par la lumière dans des semis d'arbres de forêt tropicale humide? Un test avec Dicorynia guianensis et Tachigali melinonii (Fabaceae, Caesalpinioideae).

- Les traits foliaires varient fortement avec l'éclairement mais également avec l'ontogenèse. Cependant, l'impact de l'ontogenèse sur la plasticité induite par l'éclairement reste mal connu. Les interactions entre ontogenèse et éclairement relatif ont ainsi été étudiées pour des traits fonctionnels foliaires de deux espèces de forêt tropicale humide de Guyane française : Dicorynia guianensis Amshoff et Tachigali melinonii (Harms) Barneby (Fabaceae, Caesalpinioideae).

- Onze traits morphologiques et physiologiques foliaires, relatifs aux capacités photosynthétiques, ont été mesurés sur de jeunes arbres ayant atteint trois stades architecturaux de développement successifs (ASD 1, 2 et 3 ) et utilisés pour en déduire des traits composites. Les mesures ont été réalisées le long d'un gradient naturel d'éclairement en forêt.

\footnotetext{
* Corresponding author: dreyer@nancy.inra.fr
} 
- L'impact de stades successifs de développement différait entre espèces. Pour D. guianensis, seule la masse surfacique ( $L M A)$ a augmenté significativement avec les stades de développement tandis que pour T. melinonii, presque tous les traits foliaires étaient modulés. Pour cette espèce, $L M A$, teneur en $\mathrm{N}$ et capacité photosynthétique ont augmenté de $A S D 1$ à $A S D$ 3. Par contre, l'efficience d'utilisation de $\mathrm{N}$ par la photosynthèse est restée stable entre $A S D$ s.

- Les traits foliaires ont été fortement modifiés par l'éclairement mais le degré de plasticité était similaire entre les $A S D$ s. Des interactions entre $A S D$ et éclairement n'ont été observées que pour l'épaisseur, la teneur en $\mathrm{C}$ et le rapport $\mathrm{Chl} / \mathrm{N}$ de $T$. melinonii ainsi que pour la capacité photosynthétique de $D$. guianensis.

- En dépit de l'effet significatif de l'ontogénèse sur les traits foliaires, seules de très faibles interactions ont pu être détectées avec l'éclairement pour les deux espèces. On peut en conclure que les stades successifs de développement ne modifient pas le degré de plasticité foliaire en réponse à l'éclairement tout au moins dans le cas des stades jeunes pris en compte ici.

\section{List of abbreviations and symbols}

\begin{tabular}{|c|c|c|}
\hline & Definition & Units \\
\hline$P N U E$ & Photosynthetic $\mathrm{N}$ use efficiency & \\
\hline$D P F_{\text {rel }}$ & Relative daily photon flux & $\%$ \\
\hline$H$ & Length of the main axis & $\mathrm{cm}$ \\
\hline$D$ & Basal diameter of the main axis & $\mathrm{cm}$ \\
\hline LMA & Leaf mass per unit leaf area & $\mathrm{g} \mathrm{m}^{-2}$ \\
\hline$C_{\mathrm{m}}$ & Total leaf carbon content & $\mathrm{mg} \mathrm{C} \mathrm{g}^{-1}$ \\
\hline$N_{\mathrm{m}} / N_{\mathrm{a}}$ & Total leaf nitrogen content $*$ & $\mathrm{mg} \mathrm{N} \mathrm{g}^{-1} / \mathrm{mg} \mathrm{N} \mathrm{m}^{-2}$ \\
\hline $\mathrm{Chl}_{\mathrm{m}} / \mathrm{Chl}_{\mathrm{a}}$ & Total leaf chlorophyll content $*$ & $\mu \mathrm{mol} \mathrm{Chl} \mathrm{g}-1 / \mu \mathrm{mol} \mathrm{Chl} \mathrm{m}{ }^{-2}$ \\
\hline \multicolumn{3}{|l|}{ Functional traits } \\
\hline$A_{\text {sat }} \mathrm{m} / A_{\text {sat }} \mathrm{a}$ & Light-saturated net $\mathrm{CO}_{2}$ assimilation rate & $\mathrm{nmol} \mathrm{CO} \mathrm{g}^{-1} \mathrm{~s}^{-1} / \mu \mathrm{mol} \mathrm{CO} 2 \mathrm{~m}^{-2} \mathrm{~s}^{-1}$ \\
\hline$J_{\max } / \mathrm{N}$ & Electron transport capacity per unit nitrogen & $\mu \mathrm{mol} \mathrm{CO} 2 \mathrm{mmol}^{-1} \mathrm{~N} \mathrm{~s}^{-1}$ \\
\hline $\mathrm{Chl} / \mathrm{N}$ & Investment of leaf nitrogen in chlorophyll & 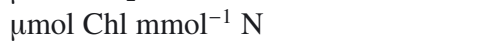 \\
\hline
\end{tabular}

* "m" and "a" denote mass-based and area-based values, respectively.

\section{INTRODUCTION}

During ontogeny, trees increase both in size and structural complexity. It is now well established that leaf and whole plant traits change with tree size (mainly height) and age (e.g. Hoflacher and Bauer, 1982; Mediavilla and Escudero, 2003; Rijkers et al., 2000; Thomas and Winner, 2002). Tree height is known to influence structural and physiological leaf traits possibly due to hydraulic constraints imposed by increased transport distance (Niinemets, 1997a; 2002; Rijkers et al., 2000). In several tropical tree species, leaf mass-per-area ratio (LMA), area-based total leaf $\mathrm{N}$ content $\left(N_{\mathrm{a}}\right)$ and area-based lightsaturated net $\mathrm{CO}_{2}$ assimilation rate $\left(A_{\text {sat }}\right.$ a $)$ increase with tree height whereas mass-based total leaf $\mathrm{N}\left(N_{\mathrm{m}}\right)$, mass-based light saturated net assimilation rate $\left(A_{\text {sat }} \mathrm{m}\right)$ and photosynthetic $\mathrm{N}$ use efficiency remain stable (Rijkers et al., 2000).
On the other hand, relative irradiance is well known to dramatically modify leaf traits, eliciting a large phenotypic plasticity (Bradshaw, 1965). In general, shade leaves are thinner, less dense and display lower leaf mass-to-area ratios (LMA) than sun-exposed leaves (Givnish, 1988; Rozendaal et al., 2006; Valladares et al., 2000). They also exhibit lower $A_{\text {sat }}$ a and dark respiration per leaf area $\left(R_{\mathrm{d}} \mathrm{a}\right)$ (Givnish, 1988; Rijkers et al., 2000). However, little is known about the modulation of irradiance-elicited plasticity by ontogeny. Many authors emphasized that, because traits vary during the course of growth and development, it is necessary to compare individuals at a common ontogenetic development stage (i.e., a common size rather than a common age) to identify environmentally induced variation in traits (Coleman et al., 1994; Poorter, 1999; Poorter et al., 2006; Veneklaas and Poorter, 1988; Wright and McConnaughay, 2002). Furthermore, growth and development 
rates themselves are highly plastic. Individuals grown under contrasted irradiance usually display different growth rates, and therefore reach largely different sizes at similar ages. Plasticity may therefore be confounded with ontogenetic responses (Veneklaas and Poorter, 1988). This was particularly emphasised in studies of shade tolerance (Lusk and Warton, 2007; Lusk et al., 2008; McConnaughay and Coleman, 1999; Niinemets, 2006).

The majority of studies addressing ontogenetic shifts of leaf traits used plant size (height, diameter or biomass) as a covariant (Poorter, 1999; Sterck and Bongers, 1998) or focused on a comparison between very young seedlings or saplings and mature trees and did not take into account any intermediate stage (Cavender-Bares and Bazzaz, 2000; Cornelissen et al., 2003; Holscher, 2004; Mediavilla and Escudero, 2003; Thomas and Winner, 2002). A meta-analysis of field measurements in saplings vs. mature trees (Thomas and Winner, 2002) showed that $A_{\text {sat }}$ a was larger in adult trees than in saplings, especially for temperate deciduous trees. An ontogenetic increase in LMA led to a decrease of $A_{\text {sat }}$ m (Mediavilla and Escudero, 2003; Roggy et al., 2005; Thomas and Winner, 2002).

The observed ontogenetic effects may also be induced by differences in tree architecture: an increased structural complexity, due to branching, crown development or occurrence of flowering may have important physiological consequences on functional leaf traits. Successive key stages of architectural development $(A S D)$ have been identified (Barthelemy and Caraglio, 2007), on the basis of the degree of structural complexity and of the expression of processes like branching, reiteration or sexuality. The successive stages may be reached at different dimensions for individual trees, depending on environmental conditions (Nicolini, 1998; Nicolini et al., 2000; Roggy et al., 2005).

The main objectives of this study were to document these questions based on observations with young individuals from two tree species growing along a natural irradiance gradient in the tropical rain forest. Dicorynia guianensis Amshoff and Tachigali melinonii (Harms) Barneby (Fabaceae, Caesalpinioideae) were selected due to their ability to establish both in the understorey and in clearings. The two species belong to the same functional group (heliophilic non pioneer species, Molino and Sabatier, 2001). More specifically, our aim was: (1) to test whether structural and functional leaf traits differed among $A S D$ s in these species; (2) to quantify the plasticity of leaf traits along a natural irradiance gradient and (3) to evidence potential interactions between irradiance and $A S D$, i.e., to test whether irradiance-elicited plasticity differed between ASDs.

In the present study, we assessed the variability of eleven morphological and physiological leaf traits related to photosynthesis over three different $A S D$ s in forests around Kourou, French Guiana. Leaf structure was assessed from leaf massto-area ratio (LMA), leaf thickness, leaf density and nitrogen, carbon and chlorophyll contents. The semi-mechanistic photosynthesis model of Farquhar et al. (1980) was used to quantify photosynthetic capacity by assessing in vivo apparent maximal Rubisco activity $\left(V_{\mathrm{cmax}}\right)$, maximal light-driven electron flux $\left(J_{\max }\right)$ and dark respiration $\left(R_{\mathrm{d}}\right)$. Photosynthetic $\mathrm{N}$ use efficiency was indirectly assessed by the ratios $V_{\mathrm{cmax}} / \mathrm{N} ; J_{\max } / \mathrm{N}$ and the relative allocation of $\mathrm{N}$ to light interception was assessed from the ratio Chlorophylls/N.

\section{MATERIAL AND METHODS}

\subsection{Study site}

The study was carried out in coastal French Guiana in South America, in the lowland tropical rain-forest of the experimental site of Paracou and in nearby sites $\left(5^{\circ} 18^{\prime} \mathrm{N}, 52^{\circ} 55^{\prime} \mathrm{W}\right)$. The climate is characterised by a wet season from December to August, interrupted during February by a short dry season, and followed by a long dry season from September to November. Average annual precipitation is $2875 \pm 540 \mathrm{~mm}$ (mean \pm SD from 1986 to 2005) with nearly two-third received between mid-March and mid-June (Baraloto et al., 2007; Bonal et al., 2000).

\subsection{Sampling}

Dicorynia guianensis Amshoff and Tachigali melinonii (Harms) Barneby (Fabaceae, Caesalpinioideae) are two rather heliophilic but non-pioneer species with compound leaves (Molino and Sabatier, 2001). D. guianensis is generally considered to be relatively tolerant to shade (Favrichon, 1994; Roggy et al., 2005). Individuals were selected at three different stages of architectural development (ASD): (1) saplings with un-branched main stem (ASD 1); (2) saplings with a sparsely branched main stem (order 2 axes remain unbranched, $A S D$ 2) and (3) immature trees with an abundantly and regularly branched main stem ( $A S D$ 3, Fig. 1). In the latter case, secondary axes are present; this stage follows the "architectural metamorphosis" during which the tree evolves from a system organised around a single main axis to a system organised around several major branches (Barthelemy and Caraglio, 2007). For more details, see descriptions in Roggy et al. (2005). 23 individuals were sampled for D. guianensis and 47 for T. melinonii. D. guianensis reaching ASD3 were only found under high irradiance and not under the full range of irradiance levels. Measurements were made from July to August 2000 for D. guianensis and during March and April 2003 for T. melinonii. The dimensions of individuals at the different $A S D$ s differed severely between the two species, and in general $D$. guianensis displayed a larger height at any given $A S D$ than T. melinonii (Fig. 2). For the tallest individuals, small scaffolds were used to access top canopy leaves from the last expanded cohort.

Daily photon flux $(D P F)$ was measured with amorphous silicon quantum sensors for photosynthetically active radiation (PAR CBE 80 Solems S.A., Palaiseau, France). DPF was measured close to each sapling (or group of saplings) at the level of the measured leaf, and compared to a reference sensor located in a clearing; this reference sensor produced an estimate of the incident irradiance above the canopy. Measurements were made over 30 consecutive days from July 20 to August 18, 2000 for D. guianensis and over at least 3 d per individual for T. melinonii during March, April 2003 and January 2004. Values of $D P F$ ranged from 0.05 to $36.7 \mathrm{~mol} \mathrm{~m}^{-2} \mathrm{~d}^{-1}$ among individuals. For each individual, relative $D P F\left(D P F_{\text {rel }}, \%\right.$ of full irradiance) was computed as the ratio of the average local and above canopy $D P F$. 


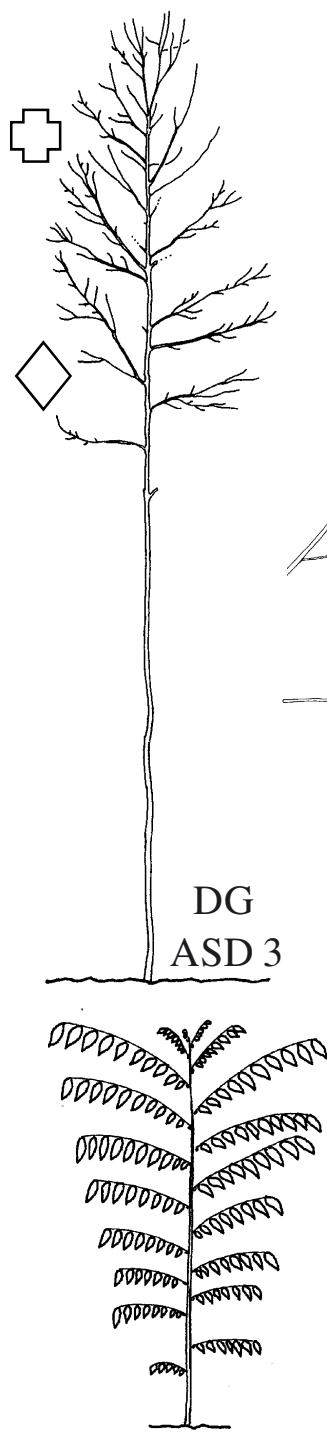

TM

ASD 1
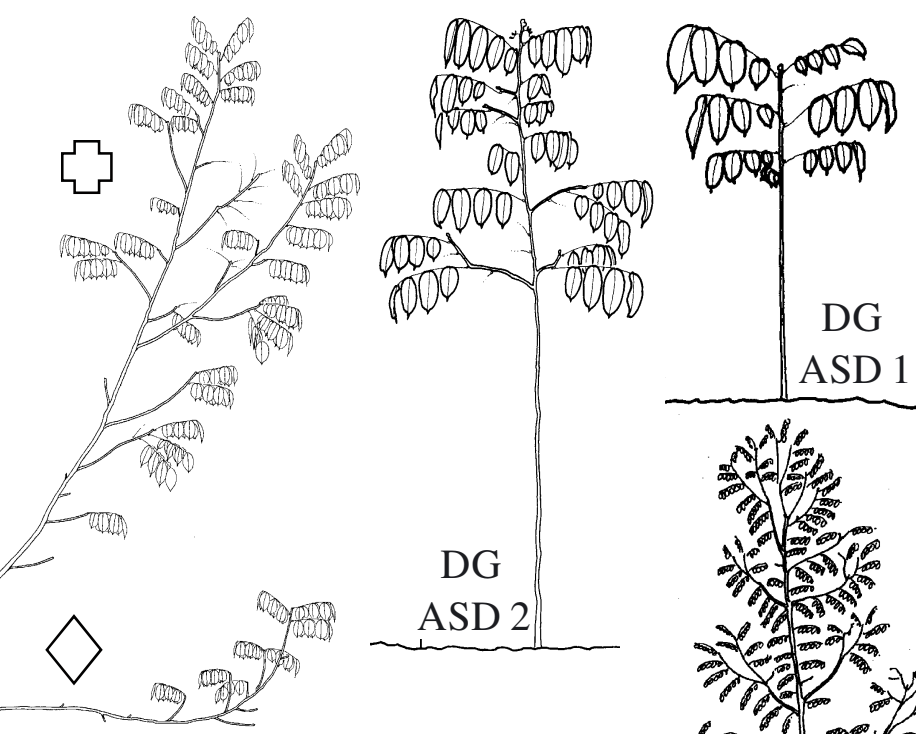

DG

ASD 1
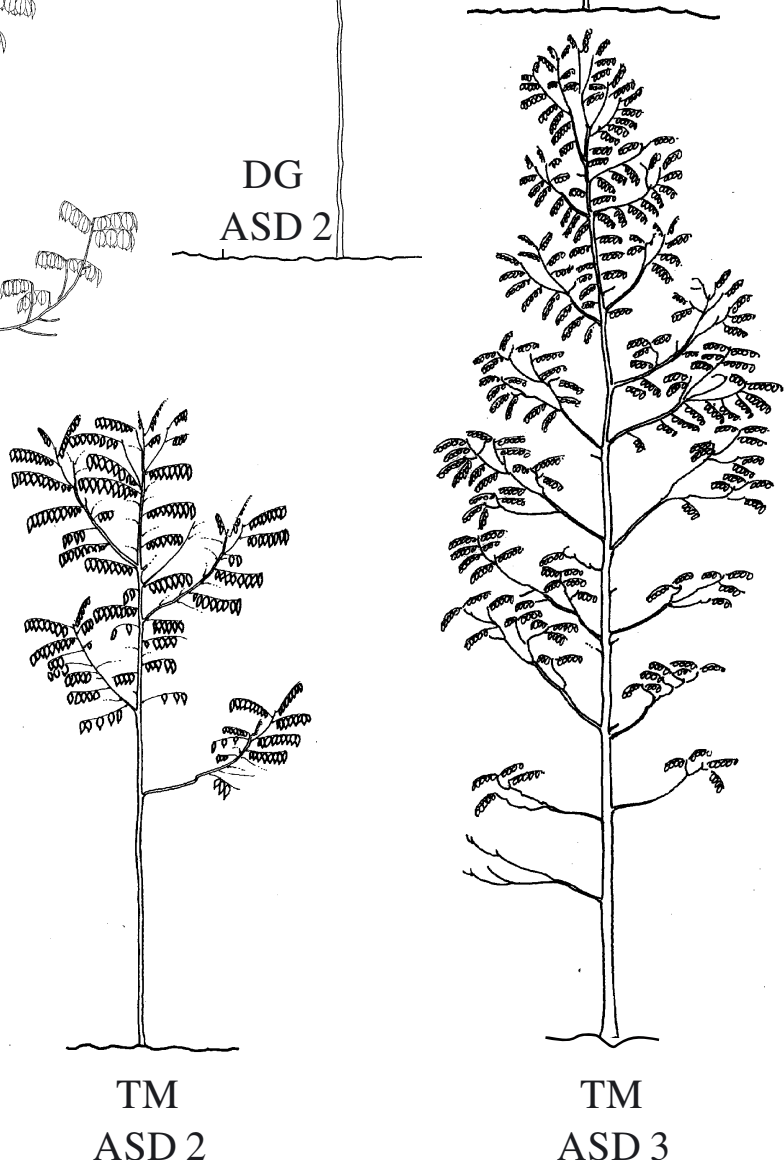

ASD 3

Figure 1. Stages of architectural development (ASD) of Dicorynia guianensis (DG) and Tachigali melinonii (TM): ASD1: saplings with unbranched main stem; $A S D 2$ : saplings with sparsely branched main stem (order 2 axes remain un-branched); $A S D 3$ : immature trees (diamonds: sequential axes; crosses: reiterated axes). For a complete description of the different ASDs, see Material and methods.

\subsection{Gas exchange measurements}

Leaf gas exchange was measured with a portable gas exchange system (CIRAS-1, PP-Systems, Hitchin, U.K.) equipped with a Parkinson leaf chamber $\left(2.5 \mathrm{~cm}^{2}\right)$. All measurements were performed on young, fully expanded leaves selected on top of the main axis, usually on the second-last growth unit of the main shoot. A halogen lamp (Philips $12 \mathrm{~V}, 20 \mathrm{~W}$ ) yielded a saturating photosynthetic photon flux density $(P P F D)$ of $700 \mu \mathrm{mol} \mathrm{m} \mathrm{m}^{-2} \mathrm{~s}^{-1}$. Air temperature in the leaf chamber and water vapor pressure deficit at the leaf surface were kept as stable as possible, but nevertheless varied significantly because of changes in the external microclimate (means $\pm \mathrm{SD}, 29 \pm 1.5^{\circ} \mathrm{C}$ and $1.6 \pm 0.2 \mathrm{kPa}$, respectively). To compensate for differences in temper- ature during measurements, all parameters were scaled to a common reference temperature $\left(T_{\text {ref }}\right)$ of $25^{\circ} \mathrm{C}(298.15 \mathrm{~K})$. Because of the lack of data for tropical tree species, we used the temperature responses computed by Dreyer et al. (2001) for seedlings of temperate forest species (Tab. I). For each leaf, a full $A-C_{i}$ curve was recorded, after induction under saturating irradiance for at least $20 \mathrm{~min}$, by stepwise changes of $\mathrm{CO}_{2}$ mole fraction in the air between 1800 and $50 \mu \mathrm{mol}$ $\mathrm{mol}^{-1}$ (5-min stabilization at each step and three successive measurements at 1-min intervals to check for stability). At least 12 measurement steps were used for each response curve. Dark respiration, $R_{\mathrm{d}}$, was recorded after $5 \mathrm{~min}$ in the dark by switching-off illumination. No correction was introduced for potential leaks in the gaskets of the chamber. 


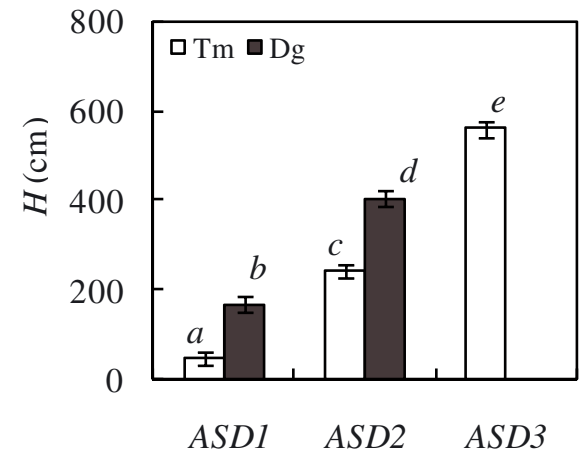

Figure 2. Effects of successive stages of architectural development (ASD 1 to 3 ) on height $(H, \mathrm{~cm})$ for T. melinonii (white) and D. guianensis (black). Values are least square means ( \pm standard error) adjusted to a common $D P F_{\text {rel }}$ of $26.1 \%$. Differences were tested with the multiple comparisons post-hoc test of Tukey $(P<0.05)$ and significant differences are indicated by different letters.

Table I. Primary parameters of the photosynthesis model used in this work. For details, see Dreyer et al. (2001).

\begin{tabular}{lcc}
\hline Parameters & Value & Unit \\
\hline$\alpha$ & 0.24 & mol electrons mol \\
& & photons \\
$K_{\mathrm{c}}\left(25^{\circ} \mathrm{C}\right)$ & 40 & $\mathrm{~Pa}$ \\
$\Delta H_{\mathrm{a}}\left(K_{\mathrm{c}}\right)$ & 70000 & $\mathrm{~J} \mathrm{~mol}^{-1}$ \\
$K_{\mathrm{o}}\left(25^{\circ} \mathrm{C}\right)$ & 25000 & $\mathrm{~Pa}$ \\
$\Delta H_{\mathrm{a}}\left(K_{\mathrm{o}}\right)$ & 15000 & $\mathrm{~J} \mathrm{~mol}^{-1}$ \\
$\left.\tau 25^{\circ} \mathrm{C}\right)$ & 2710 & - \\
$\Delta H_{\mathrm{a}}(\tau)$ & -29000 & $\mathrm{~J} \mathrm{~mol}^{-1}$ \\
\hline$\Delta H_{\mathrm{a}}\left(V_{\mathrm{cmax}}\right)^{1}$ & 73000 & $\mathrm{~J} \mathrm{~mol}^{-1}$ \\
$\Delta H_{\mathrm{a}}\left(J_{\max }\right)^{1}$ & 57900 & $\mathrm{~J} \mathrm{~mol}^{-1}$ \\
$\Delta H_{\mathrm{a}}\left(R_{\mathrm{d}}\right)^{1}$ & 32000 & $\mathrm{~J} \mathrm{~mol}^{-1}$ \\
\hline
\end{tabular}

${ }^{1}$ Mean value of $\Delta H_{\mathrm{a}}$ from seven temperate tree species (Dreyer et al., 2001).

\subsection{Estimating photosynthetic capacity}

We used the Harley et al. (1992) version of Farquhar's biochemical model of leaf photosynthesis (Farquhar et al., 1980) in which net $\mathrm{CO}_{2}$ assimilation rate $\left(A ; \mu \mathrm{mol} \mathrm{CO} \mathrm{CO}^{-2} \mathrm{~s}^{-1}\right)$ is expressed as:

$$
A=V_{\mathrm{c}}-0.5 V_{0}-R_{\mathrm{d}}
$$

where $V_{\mathrm{c}}$ is Ribulose-bisphosphate $(\mathrm{RuBP})$ carboxylation rate, $V_{\mathrm{o}}$ is $\mathrm{RuBP}$ oxygenation rate and $R_{\mathrm{d}}$ corresponds to $\mathrm{CO}_{2}$ production by non-photorespiratory respiration in the mitochondria. $A-C_{i}$ curves were used to estimate: (1) $V_{\mathrm{cmax}}$, the maximal rate of RuBP carboxylation, i.e., the potential activity of Rubisco in the absence of limitation by $\mathrm{CO}_{2}$ availability and photorespiration and (2) $J_{\max }$, the maximal light-driven electron flux. For a detailed description of the equation set, see Le Roux et al. (1999). Primary model parameters and their temperature dependencies are listed in Table I. The rate limitation by triose-phosphate availability was not estimated. Internal conductance to $\mathrm{CO}_{2}$ transfer, $g_{i}$ (Ethier and Livingston, 2004; Warren, 2006) was assumed to be infinite and the reported values of $V_{\text {cmax }}$ (and to a lesser extent $J_{\max }$ ) should therefore be considered as apparent- $V_{\text {cmax }}$ including a $g_{i}$ component. Real values of $V_{\mathrm{cmax}}$ were probably significantly larger. For each individual, a non-linear least-squares regression (Newton method, ProcNLIN, SAS v.8.1, SAS Institute Inc., Cary, NC) was used to estimate $V_{\text {cmax }}$ and $J_{\max }$ by fitting the $A-C_{i}$ curves to model equations as described by Le Roux et al. (1999).

\subsection{Leaf structure and chemistry}

After gas exchange measurements, leaves were harvested and their area measured using an electronic area meter (LiCor $3000 \mathrm{~A}$, LiCor Inc., Lincoln, NE). Thickness of each T. melinonii leaf was obtained as the mean of three measurements with a digital micrometer (Digimatic micrometer, Mitutoyo, Japan), care being taken to avoid the main veins. For D. guianensis samples, leaf thickness was estimated from anatomical samples (see Roggy et al., 2005). Leaf dry mass was recorded after drying for $48 \mathrm{~h}$ at $60{ }^{\circ} \mathrm{C}$. Total $\mathrm{N}\left(N_{\mathrm{m}}\right)$ and $\mathrm{C}$ per unit leaf dry mass $\left(C_{\mathrm{m}}\right)$ were measured with an elemental analyzer (NA 1500 NCS, Carlo Erba, Italy and SCA, CNRS Solaize, France for T. melinonii and D. guianensis, respectively). Values of $L M A, N_{\mathrm{a}}$ and leaf density ( $L M A$ /thickness) were derived from these data. A portable chlorophyll meter SPAD-502 (Minolta, Osaka, Japan) was used to estimate chlorophyll content on an area basis $\left(\mathrm{Chl}_{\mathrm{a}},\right)$. A calibration curve relating SPAD measurements and chlorophyll content was established for T. melinonii (Appendix $1^{1}$ ). Chlorophyll content was not available for D. guianensis.

Indirect estimates of photosynthetic nitrogen-use efficiency $(P N U E)$ were computed as the ratio between photosynthetic capacity and total leaf $\mathrm{N}$ content (in molar units), as $V_{\mathrm{cmax}} / \mathrm{N}, J_{\max } / \mathrm{N}$. Relative allocation of leaf $\mathrm{N}$ to light interception was assessed from the ratio $\mathrm{Chl} / \mathrm{N}$.

\subsection{Statistical analysis}

All statistical analyses were performed with STATISTICA (Kernel Version 6.0, StatSoft, Tulsa, OK, USA). Data were log-transformed to respect the required data normality and variance homogeneity, as indicated in Table and Figure legends. One-way ANCOVA, with $A S D$ as main factor and relative irradiance $\left(D P F_{\text {rel }}, \%\right)$ as covariant, was applied for each of the two species. Homogeneity of regression slopes with relative irradiance was tested. When no significant difference was detected, then the interaction term was removed from the model. Inter-specific differences were assessed using adjusted means obtained after elimination of the covariant effect. For D. guianensis, we tested only the effect of $A S D 1$ and $A S D 2$. Results of an ANCOVA with $A S D 1$ and ASD 2 only are displayed in Appendix $2^{1}$ for T. melinonii. All statistical relationships were considered significant at $P<0.05$.

\section{RESULTS}

\subsection{Size and architectural stage of development (ASD)}

Height of the saplings ranged from 71 to $1950 \mathrm{~cm}$ for $\mathrm{Di}$ corynia guianensis and from 30 to $732 \mathrm{~cm}$ for Tachigali melinonii. At all irradiance levels and ASDs, D. guianensis was

\footnotetext{
${ }^{1}$ Available online only at www.afs-journal.org
} 


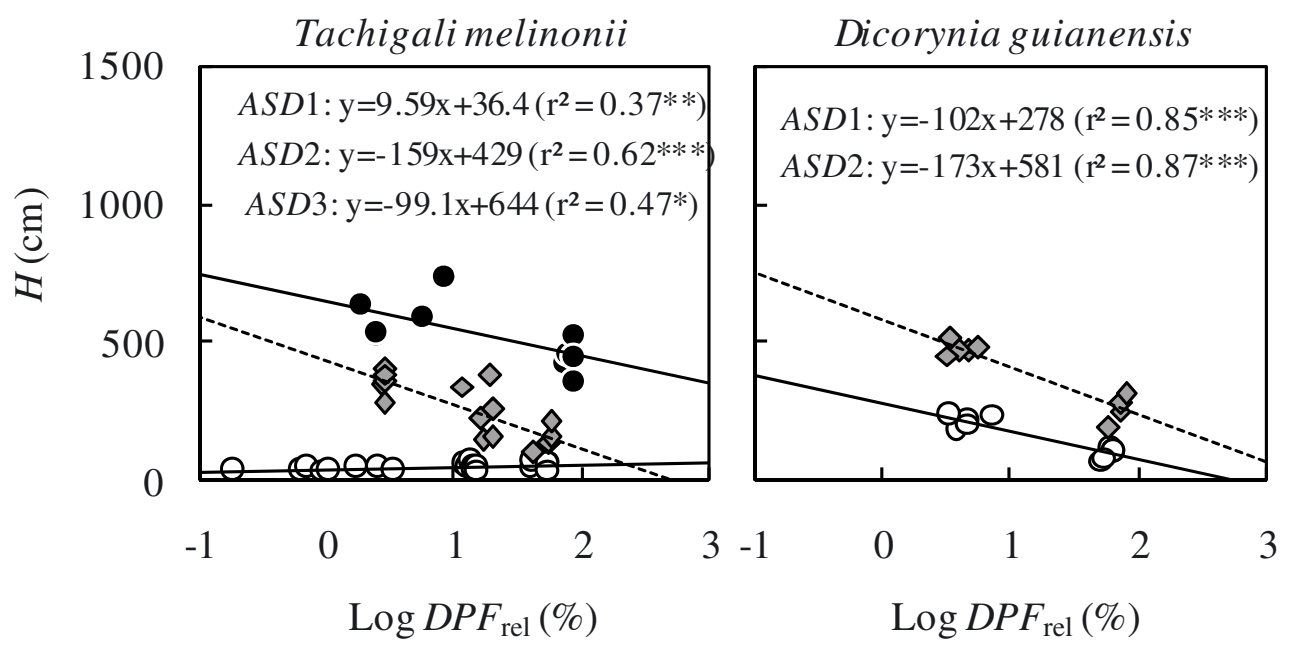

Figure 3. Relationships between height $(H, \mathrm{~cm})$ and relative daily photon flux $\left(\log D P F_{\text {rel }}\right)$ for the three stages of architectural development ( $A S D$ 1, white dots, $A S D 2$ grey diamonds and ASD 3 black dots) and for two species (T. melinonii and D. guianensis). Regression equations, level of significance $(P)$ and coefficient of determination $\left(r^{2}\right)$ are indicated for statistically significant linear regressions. Significance levels: ns, $P>0.05$; $^{*} P<0.05$; **, $P<0.01$ and $* * *, P<0.001$.

higher than T. melinonii (Fig. 2). As expected, height $(H, \mathrm{~cm})$ and basal diameter $(D, \mathrm{~cm})$ increased with successive $A S D$ s. Within a given $A S D$, larger relative daily photon flux $\left(D P F_{\text {rel }}\right)$ induced in general a decreased height (Fig. 3) and increased $D$, resulting in severely declining $H / D$ in the two species (not shown). In ASD 1, the saplings of $T$. melinonii were very small and their dimension displayed no clear response to $D P F_{\text {rel }}$.

\subsection{Effect of successive stages of $A S D$}

Mean values of leaf traits adjusted to a common irradiance and for different $A S D$ s are synthesized in Figure 4. In the two species, $A S D$ had a significant impact on several traits, but the impact was larger in T. melinonii than in D. guianensis. This was not due to the fact that we had only $2 A S D$ s in the latter and 3 in the former case. Differences observed among $A S D$ s were maintained in T. melinonii when ASD 3 was removed from the analysis (Appendix $3^{1}$ ).

In the case of $T$. melinonii, LMA, density and thickness increased from $A S D 1$ to 3 as did mass-based nitrogen content $\left(N_{\mathrm{m}}\right)$. As a consequence, area-based photosynthetic capacity ( $V_{\text {cmax }}$ a and $J_{\max }$ a) and respiration $\left(R_{\mathrm{d}} \mathrm{a}\right)$ increased from $A S D 1$ to 3 , as did, albeit to a lesser extent, mass-based photosynthetic capacity $\left(V_{\mathrm{cmax}} \mathrm{m}\right.$ and $\left.J_{\max } \mathrm{m}\right)$. Photosynthetic nitrogen-use efficiency ( $P N U E$, i.e., $V_{\mathrm{cmax}} / \mathrm{N}$ and $J_{\max } / \mathrm{N}$ ) was not affected by $A S D$, which shows that the increase of photosynthetic capacity was driven by increased $\mathrm{N}$ availability on a leaf area basis and not by a shift of $\mathrm{N}$ allocation towards photosynthesis (Tab. II, Fig. 4).

In the case of Dicorynia guianensis, leaf thickness, density, total leaf $\mathrm{N}\left(N_{\mathrm{a}}\right.$ and $\left.N_{\mathrm{m}}\right)$ and leaf $\mathrm{C}$ content $\left(C_{\mathrm{m}}\right)$ remained stable in the two $A S D$ s. The ratio $J_{\max } / V_{\text {cmax }}$ increased from $A S D 1$ to $A S D 2$, reflecting a slight increase of $J_{\max }$ with a constant $V_{\text {cmax }}$. Photosynthetic $\mathrm{N}$ use efficiency $\left(V_{\mathrm{cmax}} / \mathrm{N}\right.$ and
$J_{\max } / \mathrm{N}$ ) remained stable (Tab. III, Fig. 4). The ASD induced variability was smaller than in T. melinonii and affect less variables.

\subsection{Interactions between relative daily photon flux $\left(D P F_{\text {rel }}\right)$ and $A S D$}

The interactions between $D P F_{\text {rel }}$ and $A S D$ s were analysed separately in the two species with an ANCOVA assessing the effect of $A S D$ (factor) and $D P F_{\text {rel }}$ (covariant; Tab. II and III). For most traits, the impact of $A S D$ was much smaller than that of $D P F_{\text {rel }}$. The small level of interactions between species and $D P F_{\text {rel }}$ shows that irradiance-elicited plasticity was of similar extent in the two species (Fig. 5).

In the case of $T$. melinonii, the responses of leaf traits to $D P F_{\text {rel }}$ were as expected a large increase of $L M A$ and its components density and thickness, an increase of area-based photosynthetic capacity and leaf $\mathrm{N}$ content (Fig. 5). Mass-based photosynthetic capacity did not change with $D P F_{\text {rel }}$ confirming that modulation of $L M A$ and nitrogen content per area $\left(N_{\mathrm{a}}\right)$ were the main drivers of the effects of $D P F_{\text {rel }}$ on photosynthesis. As a consequence, $P N U E$ increased slightly with increases in $D P F_{\text {rel }}$ (Tab. II, Fig. 5). Only few interactions were detected between $A S D$ and $D P F_{\text {rel }}$ : thickness, $C_{\mathrm{m}}$ and $\mathrm{Chl} / \mathrm{N}$ displayed such interactions that resulted in only minor changes in the relationship with $D P F_{\text {rel }}$ at a given $A S D$ (Tab. II, Fig. 6).

In the case of Dicorynia guianensis, $D P F_{\text {rel }}$ affected all leaf traits except area based photosynthetic capacity and photosynthetic $\mathrm{N}$ use efficiency. $L M A$ and to a lesser extent, leaf thickness, density and total leaf $\mathrm{N}$ content significantly increased along the $D P F_{\text {rel }}$ gradient (Fig. 5). Leaf $\mathrm{C}$ content $\left(C_{\mathrm{m}}\right)$ was unaffected by $D P F_{\text {rel }}$ and by $A S D$ (Tab. III). The relationship between $V_{\text {cmax }}$ a and $D P F_{\text {rel }}$ differed according to $A S D$ : $V_{\text {cmax }}$ a ranged from 21.5 to $31.5 \mu \mathrm{mol} \mathrm{m}{ }^{-2} \mathrm{~s}^{-1}$ in $A S D 2$ 

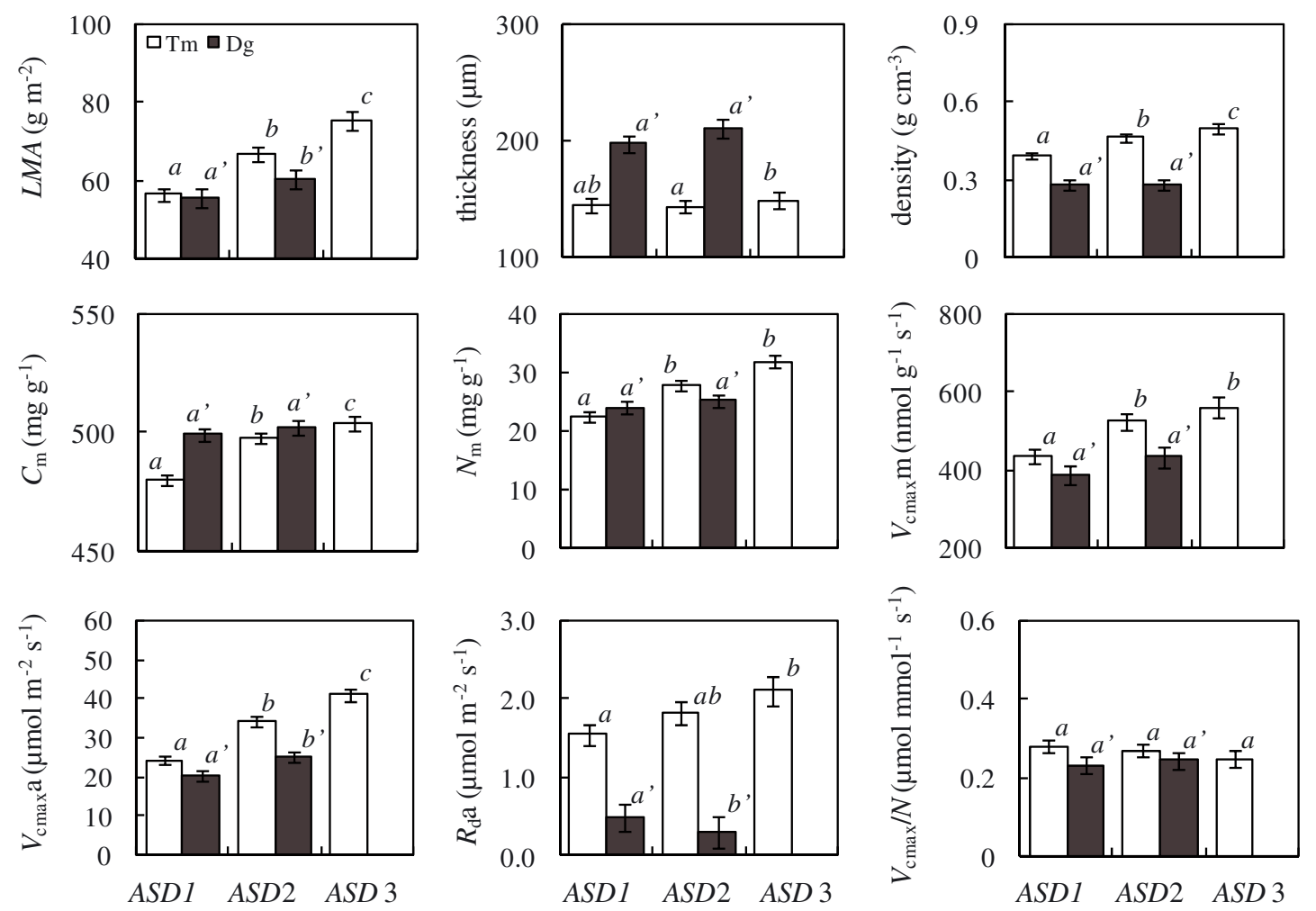

Figure 4. Effects of stages of architectural development (ASD 1 to 3) on leaf traits for T. melinonii (white) and D. guianensis (black). Values are least square means ( \pm Standard error) adjusted at a common relative daily photon flux $\left(D P F_{\text {rel }}=26.1 \%\right)$. Significant differences were tested with the multiple comparisons post-hoc test of Tukey $(P<0.05)$ and indicated by different letters $\left(a, b, c\right.$ for T. melinonii and $a^{\prime}, b^{\prime} c^{\prime}$ for D. guianensis).
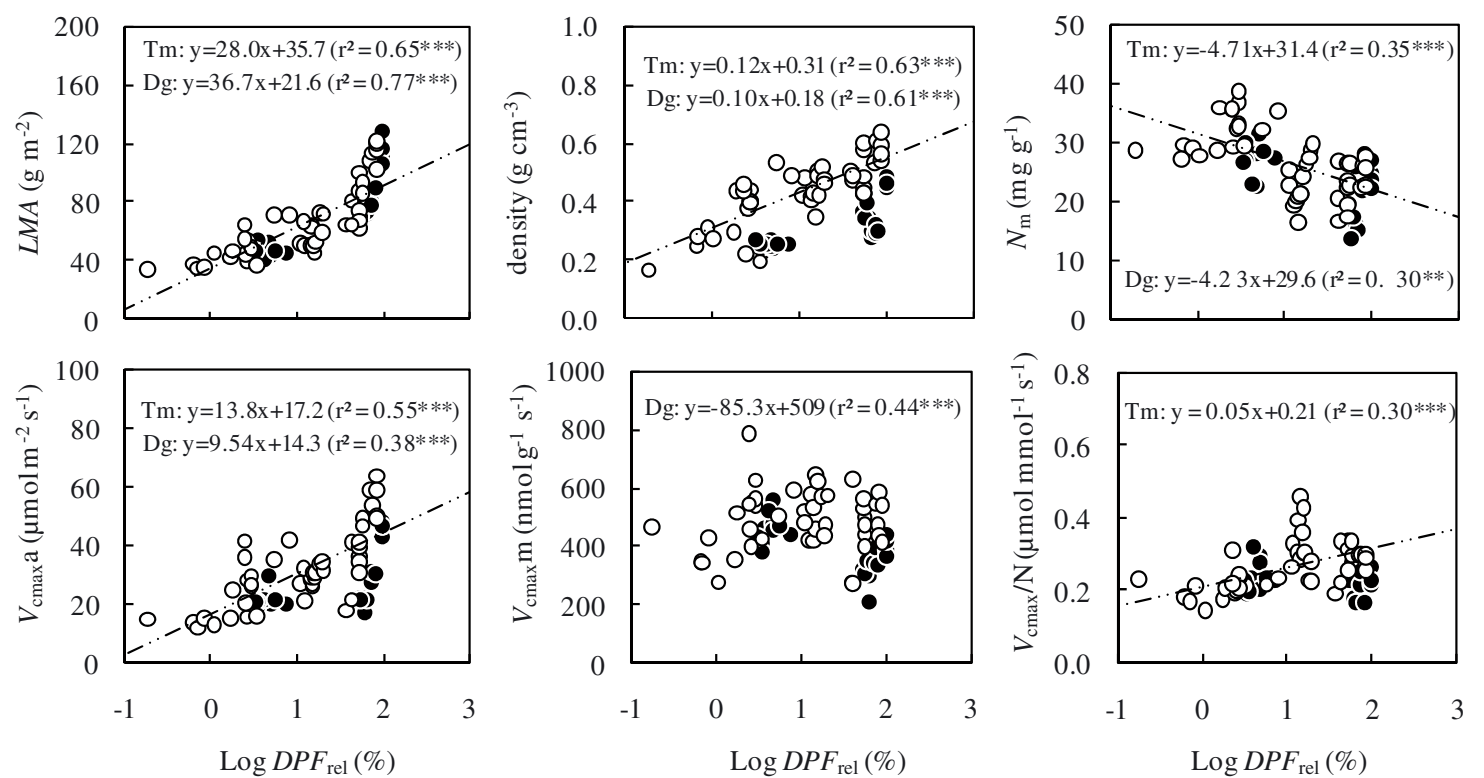

Figure 5. Relationships between leaf traits and relative daily photon flux ( $\left.\log D P F_{\text {rel }}\right)$ for T. melinonii (white dots) and D. guianensis (black dots). Simple linear regressions were represented by solid lines for $T$. melinonii and by dotted lines for $D$. guianensis. Regression equation and $r^{2}$ are indicated for statistically significant linear regressions $(P<0.05)$. Significance levels: ns, $P>0.05 ; *, P \leqslant 0.05 ; * *, P \leqslant 0.01 ; * * *$ and $P \leqslant 0.001$. 
Table II. Results of a one-way Ancova with stage of architectural development $(A S D=3)$ as main factor and relative irradiance $\left(D P F_{\text {rel }}\right.$, $\%)$ as covariant for Tachigali melinonii. $F$-values, levels of significance $(P)$ and coefficients of determination $\left(r^{2}\right)$ of the model are given. $D P F_{\text {rel }}, H, D, L M A, N_{\mathrm{a}}$ and $J_{\max }$ a were log-transformed prior to analysis. $C_{\mathrm{m}}$ and thickness were analyzed with a separate slope model. $V_{\text {cmax }} \mathrm{m}, J_{\max } \mathrm{m}$ and $R_{\mathrm{d}} \mathrm{m}$ were not linearly correlated with $D P F_{\text {rel }}$ and thus they were analyzed with a one way ANOVA. Significance levels: ns, $P>0.05$; $^{*} P<0.05$; **, $P<0.01$ and $* * *$, $P<0.001$. The corresponding adjusted means at a $26 \% D P F_{\text {rel }}$ are displayed in Figure 4 and numerical values are provided in the on-line only Appendix 2.

\begin{tabular}{|c|c|c|c|c|}
\hline & $A S D$ & $D P F_{\text {rel }}$ & $D P F_{\text {rel }} \times A S D$ & model \\
\hline & $F$ & $F$ & $F$ & $r^{2}$ \\
\hline$H$ & $226 * * *$ & - & $15.9 * * *$ & 0.96 \\
\hline$D$ & $72.6 * * *$ & - & $23.0 * * *$ & 0.94 \\
\hline \multicolumn{5}{|c|}{ Structural traits } \\
\hline$L M A$ & $26.5 * * *$ & $183 * * *$ & _ & 0.88 \\
\hline thickness & $8.63 * * *$ & _ & $121 * * *$ & 0.55 \\
\hline density & $19 * * *$ & $90.9 * * *$ & _ & 0.80 \\
\hline$N_{\mathrm{a}}$ & $76.4 * * *$ & $20.3^{* * *}$ & - & 0.84 \\
\hline$N_{\mathrm{m}}$ & $38.6 * * *$ & $102 * * *$ & _ & 0.77 \\
\hline$C_{\mathrm{m}}$ & $18.3 * * *$ & _ & $9.35 * * *$ & 0.75 \\
\hline $\mathrm{Chl}_{\mathrm{a}}$ & $24.3 * * *$ & $52.1 * * *$ & - & 0.65 \\
\hline $\mathrm{Chl}_{\mathrm{m}}$ & $1.9 \mathrm{~ns}$ & $189 * * *$ & _ & 0.82 \\
\hline \multicolumn{5}{|c|}{ Physiological traits } \\
\hline$V_{\text {cmax }} \mathrm{a}$ & $49.7 * * *$ & $98 * * *$ & _ & 0.86 \\
\hline$J_{\max } \mathrm{a}$ & $40.2 * * *$ & $176^{* * *}$ & - & 0.89 \\
\hline$R_{\mathrm{d}} \mathrm{a}$ & $3.44 *$ & $18.1 * * *$ & _ & 0.45 \\
\hline$V_{\mathrm{cmax}} \mathrm{m}$ & $6.85^{* *}$ & ns & _ & 0.24 \\
\hline$J_{\max } \mathrm{m}$ & $5.40 * *$ & ns & - & 0.20 \\
\hline$R_{\mathrm{d}} \mathrm{m}$ & $0.62 \mathrm{~ns}$ & ns & - & 0.03 \\
\hline$J_{\max } / V_{\text {cmax }}$ & $1.15 \mathrm{~ns}$ & $7.76^{* *}$ & _ & 0.16 \\
\hline$V_{\text {cmax }} / \mathrm{N}$ & $1.29 \mathrm{~ns}$ & $22.4 * * *$ & _ & 0.34 \\
\hline$J_{\max } / N$ & $2.76 \mathrm{~ns}$ & $49.7 * * *$ & - & 0.54 \\
\hline $\mathrm{Chl} / N$ & $9.06 * *$ & _- & $56.3 * * *$ & 0.85 \\
\hline
\end{tabular}

whereas no plasticity was detected in $A S D 1$ (Fig. 7). Massbased photosynthetic capacities $\left(V_{\mathrm{cmax}} \mathrm{m}, J_{\max } \mathrm{m}\right)$ increased with $D P F_{\text {rel }}$ while $R_{\mathrm{d}} \mathrm{m}$ decreased. Photosynthetic N use efficiency $\left(V_{\text {cmax }} / \mathrm{N}\right.$ and $\left.J_{\max } / \mathrm{N}\right)$ remained unaffected by $D P F_{\text {rel }}$ (Tab. III).

\section{DISCUSSION}

Here we tested whether increasing structural complexity, as described by successive stages of architectural development $(A S D)$ has an impact on individual leaf traits. We chose to compare three successive $A S D$ s of young trees to evidence ontogenetic shifts in leaf traits. Nevertheless, we are aware that dimension, size and structural complexity are inter-related properties in trees, and that it is therefore uneasy to separate
Table III. Results of a one-way Ancova with stage of architectural development ( $A S D 1$ and $A S D 2$ ) as main factor and relative $D P F$ $\left(D P F_{\text {rel }}, \%\right)$ as covariant applied to Dicorynia guianensis. $F$-value, level of significance $(P)$ and coefficient of determination $\left(r^{2}\right)$ of the model are given. $D P F_{\text {rel }}, H, D$ and $J_{\max }$ a were log-transformed prior to analysis. $V_{\text {cmax }}$ a was analyzed with a separate slope model. $D$, $C_{\mathrm{m}}, J_{\max } \mathrm{a}, J_{\max } / V_{\mathrm{cmax}}, V_{\mathrm{cmax}} / \mathrm{N}$ and $J_{\max } / \mathrm{N}$ were not linearly correlated with $D P F_{\text {rel }}$ and thus they were analyzed with a one way ANOVA. Significance levels: ns, $P>0.05$; * $P<0.05$; **, $P<0.01$ and $* * *, P<0.001$. The corresponding adjusted means at $26 \%$ $D P F_{\text {rel }}$ are displayed in Figure 4 and numerical values are provided in the on-line only Appendix 2.

\begin{tabular}{|c|c|c|c|c|}
\hline & $A S D$ & $D P F_{\text {rel }}(\%)$ & $D P F_{\text {rel }} \times A S D$ & model \\
\hline & $F$ & $F$ & $F$ & $r^{2}$ \\
\hline$H$ & $110 * * *$ & $66.0 * * *$ & - & 0.92 \\
\hline$D$ & $74.4 * * *$ & ns & - & 0.81 \\
\hline \multicolumn{5}{|c|}{ Structural traits } \\
\hline$L M A$ & $7.78^{*}$ & $164 * * *$ & - & 0.91 \\
\hline thickness & $2.99 \mathrm{~ns}$ & $30 * * *$ & - & 0.67 \\
\hline density & $0.16 \mathrm{~ns}$ & $25.7 * * *$ & - & 0.62 \\
\hline$N_{\mathrm{a}}$ & $4.13 \mathrm{~ns}$ & $5.84 *$ & - & 0.37 \\
\hline$N_{\mathrm{m}}$ & $0.66 \mathrm{~ns}$ & $12.5^{* *}$ & - & 0.46 \\
\hline$C_{\mathrm{m}}$ & $0.3 \mathrm{~ns}$ & ns & - & 0.02 \\
\hline \multicolumn{5}{|c|}{ Physiological traits } \\
\hline$V_{\text {cmax }} \mathrm{a}$ & $0.01 \mathrm{~ns}$ & - & $11.7 * * *$ & 0.77 \\
\hline$J_{\max } \mathrm{a}$ & $13.1 * *$ & ns & - & 0.44 \\
\hline$R_{\mathrm{d}} \mathrm{a}$ & $6.87 *$ & $160 * * *$ & - & 0.91 \\
\hline$V_{\text {cmax }} \mathrm{m}$ & $3.79 \mathrm{~ns}$ & $32.3 * * *$ & - & 0.70 \\
\hline$J_{\max } \mathrm{m}$ & $6.24 *$ & $21.2 * * *$ & - & 0.64 \\
\hline$R_{\mathrm{d}} \mathrm{m}$ & $13.6 * *$ & $89.2 * * *$ & - & 0.87 \\
\hline$J_{\max } / V_{\mathrm{cmax}}$ & $6.4^{*}$ & ns & - & 0.27 \\
\hline$V_{\text {cmax }} / \mathrm{N}$ & $0.14 \mathrm{~ns}$ & ns & - & 0.01 \\
\hline$J_{\max } / \mathrm{N}$ & $0.94 \mathrm{~ns}$ & ns & _- & 0.05 \\
\hline
\end{tabular}

the effects of tree dimensions from those of structural complexity (i.e., $A S D$ s). This is illustrated by the fact that height and basal diameter of the sampled individuals were always much larger in $A S D 3$ than in $A S D$ 1. The time-course of successive $A S D$ s is modulated by environment, and faster transitions from an $A S D$ to the next one occur under favorable growth conditions (Barthelemy and Caraglio, 2007). Indeed, branching and crown development occur later and at a larger height in the understorey than in open areas. Consequently, a given $A S D$ can be reached at different total heights and at different chronological ages depending on environmental conditions (Nicolini et al., 2000; Roggy et al., 2005). In our case, it was unfortunately impossible to retrospectively estimate the real age of the sampled young trees and we are unable to disentangle the effects of age, dimension and ASDs.

\subsection{Differences in leaf traits among $A S D s$}

Structural and physiological leaf traits were affected by ASDs (i.e., ontogeny) in saplings of Tachigali melinonii and 

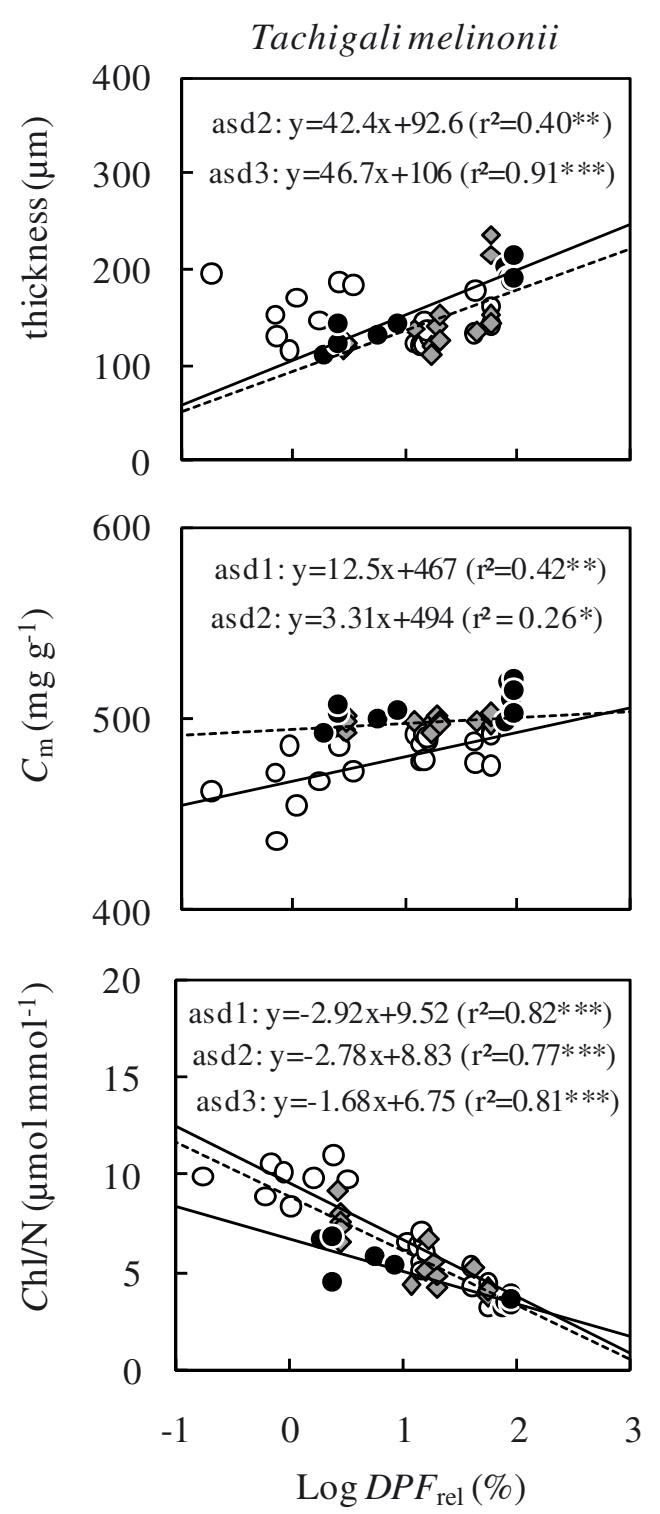

Figure 6. Relationships between leaf thickness $(\mu \mathrm{m})$, leaf $C$ content $\left(C_{\mathrm{m}}, \mathrm{mg} \mathrm{g}^{-1}\right)$, ratio of chlorophyll content on $\mathrm{N}$ content $(\mathrm{Chl} / \mathrm{N}, \mu \mathrm{mol}$ $\left.\mathrm{mmol}^{-1}\right)$ and relative daily photon flux $\left(\log D P F_{\text {rel }}, \%\right)$ for the three stages of architectural development ( $A S D$ 1, white dots, $A S D 2$ grey diamonds and ASD 3 black dots) of Tachigali melinonii. Regression equations, level of significance $(P)$ and coefficient of determination $\left(r^{2}\right)$ are indicated for statistically significant linear regressions. Significant levels: ns, $P>0.05$; $* P<0.05$; ** $P<0.01$ and $* * *$ $P<0.001$.

Dicorynia guianensis. We concentrated on juvenile stages of development because they are of central importance for the regeneration of forest stands. At this stage, selection of individuals and species is the most severe during the life-cycle of a forest ecosystem. Moreover, ontogeny and responses to irradiance are major factors that influence the ability of a species to outcompete neighbouring species and to survive in older stages of the forest (Valladares and Niinemets, 2008).

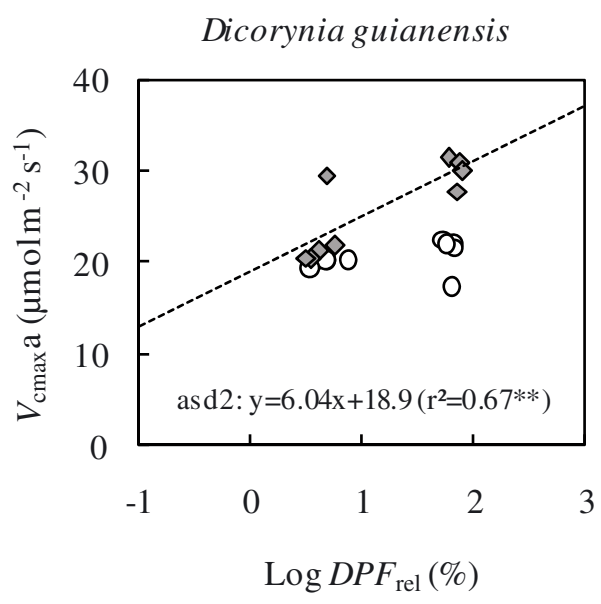

Figure 7. Relationships between $V_{\mathrm{cmax}}$ a $\left(\mu \mathrm{mol} \mathrm{m} \mathrm{m}^{-2} \mathrm{~s}^{-1}\right)$ and relative daily photon flux $\left(\log D P F_{\text {rel }}, \%\right)$ for the three architectural stage of development ( $A S D$ 1, white dots and ASD 2 grey diamonds) of $\mathrm{Di}$ corynia guianensis. Regression equations, levels of significance $(P)$ and coefficient of determination $\left(r^{2}\right)$ are indicated for statistically significance linear regressions. Significance levels: ns, $P>0.05$; $* P<0.05$; ** $P<0.01$ and $* * * P<0.001$.

Leaf mass-to-area ratio (LMA) is known to display large ontogenetic shifts as well as irradiance-elicited plasticity: it increases with age and with relative irradiance (e.g. Lusk and Warton, 2007; Niinemets, 1999a, 2006; Thomas and Winner, 2002). In the present study we observed a significant increase of LMA with the sequence of $A S D$ s in juvenile T. melinonii and to a lesser extent $D$. guianensis. Such an increase can be attributed to different factors:

(i) Increased thickness, in particular of the palisade parenchyma as observed by Kenzo et al. (2006) in some dipterocarp species. This was probably the case in T. melinonii (and to a lesser extent in D. guianensis) where leaf thickness increased with $A S D$ s;

(ii) Increased leaf density due to enhanced investment into structural support required to sustain larger lamina (Lusk and Warton, 2007 and references therein); increased density was indeed recorded in T. melinonii but again not in D. guianensis;

(iii) Increased structural complexity due to the occurrence of branching may lead to restrictions of water supply to leaves due to hydraulic constrictions at branch bases; they may constrain leaf growth and result in smaller leaves (Niinemets, 2002; Thomas and Winner, 2002). To our knowledge, the impact of successive ASDs on hydraulic properties has never been explicitly addressed.

In general, the ontogenetic increase in LMA leads in parallel to an increase in area-based and a stability of mass-based photosynthesis (Mediavilla and Escudero, 2003; Niinemets, 2002; Roggy et al., 2005; Thomas and Winner, 2002). Photosynthetic capacity increased in successive ASDs: area-based apparent maximal carboxylation rate $\left(V_{\text {cmax }} a\right)$ increased from 25 to 41 and from 20 to $26 \mu \mathrm{mol} \mathrm{m} \mathrm{m}^{-2} \mathrm{~s}^{-1}$ for T. melinonii and D. guianensis, respectively. The effect on mass-based 
photosynthetic capacity was much smaller but still significant; this confirms that changes in area-based photosynthesis were mainly driven by variations in LMA. Parallel to photosynthetic capacity, total leaf $\mathrm{N}$ content increased with ontogenetic stages for $T$. melinonii whereas it remained constant for D. guianensis. As a consequence, photosynthetic N useefficiency, measured here as the ratio of $V_{\mathrm{cmax}} / \mathrm{N}$ and $J_{\max } / \mathrm{N}$, was stable among $A S D$ s. A slight decline of the ratio $\mathrm{Chl} / \mathrm{N}$ was mainly due to increasing $\mathrm{N}$ content, whereas $\mathrm{Chl}_{\mathrm{m}}$ did not differ among $A S D$ s (for T. melinonii).

$V_{\text {cmax }}$ and $J_{\max }$ increased in parallel, leading to a stability of the ratio among the three stages for T. melinonii. For D. guianensis, the ratio $J_{\max } / V_{\text {cmax }}$ slightly increased from $A S D 1$ to $A S D$ 2. Such a variability may be related to the method used to estimate the two parameters. We assumed an infinite value of internal leaf conductance $\left(g_{i}\right)$ whereas recent studies have shown that $g_{i}$ is not negligible and may result in a significant underestimation of $V_{\text {cmax }}$ (Ethier and Livingston, 2004).

These results indicate that ontogenetic events like the development of branching do not necessarily induce similar effects on leaf traits in different species. Nevertheless, in the case of D. guianensis larger changes in leaf structure or physiology may appear at later ontogenetic stages, with the development of a complex crown for instance.

\subsection{Difference in irradiance-induced plasticity of leaf traits among $A S D s$}

As expected, irradiance affected a large majority of structural and physiological leaf traits, on-line with a number of published results (Givnish, 1988; Rozendaal et al., 2006; Valladares et al., 2000). However, irradiance-elicited plasticity could differ between ASDs (Wright and McConnaughay, 2002). LMA, leaf thickness and density increased as expected with increasing relative irradiance (Popma et al., 1992; Rijkers et al., 2000; Rozendaal et al., 2006; Valladares et al., 2000). Total leaf $\mathrm{N}$ decreased while a relative stability was expected from the literature (Ellsworth and Reich, 1993; Niinemets, 1997b; Niinemets and Kull, 1998; Rijkers et al., 2000). However this result fits with observations on co-occurring species of French Guiana grown in an experimental shade-house (Coste, 2008). Consequently, the increase of area-based nitrogen was mainly due to the large plasticity of $L M A$. Shade leaves generally display also higher $\mathrm{Chl}_{\mathrm{m}}$ (e.g. Poorter et al., 1995; Rijkers et al., 2000) which was confirmed here. Plasticity of leaf $\mathrm{C}$ content, $C_{\mathrm{m}}$, differed between species. Thus $C_{\mathrm{m}}$ tended to increase for T. melinonii while it remained constant with irradiance (as with ontogeny) for D. guianensis. This result is consistent with the significant interspecific-diversity of irradiance-elicited plasticity of leaf specific construction costs (strongly correlated to $C_{\mathrm{m}}$ ) put in evidence in co-occurring species (Coste, 2008).

It is generally accepted that area-based photosynthetic capacity increases with irradiance (Givnish, 1988; Rijkers et al., 2000), mainly as a consequence of structural adjustment (Niinemets, 1999a; Roggy et al., 2005) which is confirmed by our results. A similar plasticity, was observed in the two species for a majority of leaf traits. However, massbased photosynthetic capacity $\left(V_{\mathrm{cmax}} \mathrm{m}, J_{\max } \mathrm{m}\right.$ and $R_{\mathrm{d}} \mathrm{m}$ ) was not affected by irradiance in $T$. melinonii whereas it significantly decreased with increasing irradiance for D. guianensis. Conversely, $P N U E$ (i.e., both $V_{\text {cmax }} / \mathrm{N}$ and $J_{\max } / \mathrm{N}$ ) increased with irradiance for $T$. melinonii whereas no effect was observed for D. guianensis.

Globally, irradiance-elicited plasticity remained constant among $A S D$ s in the two species, i.e., only small interaction effects were detected between relative irradiance and ontogeny. This may not hold true when scaling up to branch and to crown level; it was indeed shown that ontogeny has an important effect on the plastic responses to light for traits at higher hierarchical scale (Valladares and Niinemets, 2008).

In T. melinonii leaf thickness and carbon content were independent of irradiance in ASD 1 while density increased; this contradicts partly the hypothesis that high leaf density may be partly associated with the presence of tissues with high lignin contents (Niinemets, 1999b; Niinemets and Kull, 1998).

We found only little interaction between ASDs and irradiance, and inter-specific differences were maintained along ontogenetic stages and irradiance. The two species are known to be rather shade-intolerant and the observed differences cannot be attributed to different ecological requirements. Moreover, to characterize shade tolerance as a trait, there is a need to scale up from leaf to at least branch level (if not canopy level) and to take into account potential effects of leaf life span (Lusk and Warton, 2007; Lusk et al., 2008; Niinemets, 2006; Valladares and Niinemets, 2008). Taking into account such integrative traits would be a target for future developments in the assessment of potential interactions between ontogeny and irradiance on tree physiology and carbon balance.

\section{CONCLUSION}

The present study, conducted in tropical rain forests, showed for two species that three successive ontogenetic stages of development induced visible changes in leaf traits, close to those described in other species (increased leafmass-to area ratio, increased area-based photosynthesis). The expected irradiance-elicited plasticity in these traits was also observed, with basically large increases in leaf-mass-to area ratio, and in area-based photosynthetic capacity. There was almost no interaction between the plastic response and the ontogenetic stage: we observed a similar plasticity at all stages and in the two species with the exception of a few minor traits. Such results also underline that leaf life-span and more integrative traits, like branch properties, should equally be considered when addressing the potential interactions between irradiance-elicited plasticity and ontogenic development.

Acknowledgements: S. Coste was supported by a $\mathrm{PhD}$ grant from the French ministry for higher education and research, and by a grant for technical cooperation in overseas regions of France. The authors are indebted to Jacqueline Marchand for carbon and nitrogen analyses and to Pascal Imbert and Julien Bachelier for their help throughout the experiment Particular thanks are due to Meriem Fournier, head of 
the UMR Ecofog at the time of this research, for continuous support and encouragement.

\section{REFERENCES}

Baraloto C., Morneau F., Bonal D., Blanc L., and Ferry B., 2007. Seasonal water stress tolerance and habitat associations within four neotropical tree genera. Ecology 88: 478-489.

Barthelemy D. and Caraglio Y., 2007. Plant architecture: A dynamic, multilevel and comprehensive approach to plant form, structure and ontogeny. Ann. Bot. 99: 375-407.

Bonal D., Sabatier D., Montpied P., Tremeaux D., and Guehl J.M., 2000. Interspecific variability of $\delta^{13} \mathrm{C}$ among trees in rainforests of French Guiana: functional groups and canopy integration. Oecologia 124: 454-468.

Bradshaw A.D., 1965. Evolutionary significance of phenotypic plasticity in plants. Adv. Genet. 13: 115-155.

Cavender-Bares J. and Bazzaz F.A., 2000. Changes in drought response strategies with ontogeny in Quercus rubra: implications for scaling from seedlings to mature trees. Oecologia 124: 8-18.

Coleman J.C., McConnaughay K.D.M., and Ackerly D.D., 1994. Interpreting phenotypic variation in plants. Trends Ecol. Evol. 9: 187-191.

Cornelissen J.H.C., Cerabolini B., Castro-Díez P., Villar-Salvador P., Montserrat-Martí G., Puyravaud J.P., Maestro M., Werger M.J.A., and Aerts R., 2003. Functional traits of woody plants: correspondence of species rankings between field adults and laboratory-grown seedlings? J. Veg. Sci. 14: 311-322.

Coste S., 2008. Diversité et plasticité des traits foliaires en forêt tropicale humide. Une analyse coût/bénéfice de l'acquisition de carbone, Ph.D. thesis, Nancy, AgroParisTech-Engref.

Dreyer E., Le Roux X., Montpied P., Daudet F.A., and Masson F., 2001. Temperature response of leaf photosynthetic capacity in seedlings from seven temperate tree species. Tree Physiol. 21: 223-232.

Ellsworth D.S. and Reich P.B., 1993. Canopy structure and vertical patterns of photosynthesis and related leaf traits in a deciduous forest. Oecologia 96: 169-178.

Ethier G.J. and Livingston N., 2004. On the need to incorporate sensitivity to $\mathrm{CO}_{2}$ transfer conductance into the Farquhar-von CaemmererBerry leaf photosynthesis model. Plant Cell Environ. 27: 137-153.

Farquhar G.D., von Caemmerer S., and Berry J.A., 1980. A biochemical model of photosynthetic $\mathrm{CO}_{2}$ assimilation in leaves of $\mathrm{C}_{3}$ species. Planta 149: 78-90.

Favrichon V., 1994. Classification des espèces arborées en groupes fonctionnels en vue de la réalisation d'un modèle de dynamique de peuplement en forêt guyanaise. Rev. Ecol. (terre et vie) 49: 379-403.

Givnish T.J., 1988. Adaptation to sun and shade: A whole plant perspective. Aust. J. Plant. Physiol. 15: 63-92.

Harley P.C., Thomas R.B., Reynolds J.F., and Strain B.R., 1992. Modelling photosynthesis of cotton grown in elevated $\mathrm{CO}_{2}$. Plant Cell Environ. 15: 271-282.

Hoflacher H. and Bauer H., 1982. Light acclimation in leaves of the juvenile and adult life phases of ivy (Hedera helix). Physiol. Plant. 56: 177-182.

Holscher D., 2004. Leaf traits and photosynthetic parameters of saplings and adult trees of co-existing species in a temperate broad-leaved forest. Bas. App. Ecol. 5: 163-172.

Kenzo T., Ichie T., Watanabe Y., Yoneda R., Ninomiya I., and Koike T., 2006. Changes in photosynthesis and leaf characteristics with tree height in five dipterocarp species in a tropical rain forest. Tree Physiol. 26: 865-873.
Le Roux X., Grand S., Dreyer E., and Daudet F.A., 1999 Parameterization and testing of a biochemically based photosynthesis model for walnut trees (Juglans regia) and seedlings. Tree Physiol. 19: 481-492.

Lusk C.H. and Warton D.I., 2007. Global meta-analysis shows that relationships of leaf mass per area with species shade tolerance depend on leaf habit and ontogeny. New Phytol. 176: 764-774.

Lusk C.H., Falster D.S., Jara-Vergara C.K., Jimenez-Castillo M., and Saldana-Mendoza A., 2008. Ontogenetic variation in light requirements of juvenile rainforest evergreens. Funct. Ecol. 22: 454-459.

McConnaughay K.D.M. and Coleman J.S., 1999. Biomass allocation in plants: ontogeny or optimality? A test along three resource gradients. Ecology 80: 2581-2593.

Mediavilla S. and Escudero A., 2003. Mature trees versus seedlings: Differences in leaf traits and gas exchange patterns in three cooccurring Mediterranean oaks. Ann. For. Sci. 60: 455-460.

Molino J.-F. and Sabatier D., 2001. Tree diversity in tropical rain forests: A validation of the intermediate disturbance hypothesis. Science 294: 1702-1704.

Nicolini E., 1998. Architecture et gradients morphogénétiques chez de jeunes hêtres (Fagus sylvatica L. Fagaceae) en milieu forestier. Can. J. Bot. 76: 1232-1244.

Nicolini E., Barthélémy D., and Heuret P., 2000. Influence de la densité du couvert forestier sur le développement architectural de jeunes chênes sessiles, Quercus petraea (Matt.) Liebl. (Fagaceae), en régénération forestière. Can. J. Bot. 78: 1531-1344.

Niinemets Ü., 1997a. Distribution patterns of foliar carbon and nitrogen as affected by tree dimensions and relative light conditions in the canopy of Picea abies. Trees 11: 144-154.

Niinemets Ü., 1997b. Role of foliar nitrogen in light harvesting and shade tolerance of four temperate deciduous woody species. Funct. Ecol. 11: $518-531$.

Niinemets Ü., 1999a. Components of leaf dry mass per area - thickness and density - alter leaf photosynthetic capacity in reverse directions in woody plants. New Phytol. 144: 35-47.

Niinemets Ü., 1999b. Energy requirement for foliage formation is not constant along canopy light gradients in temperate deciduous trees. New Phytol. 141: 459-470.

Niinemets Ü., 2002. Stomatal conductance alone does not explain the decline in foliar photosynthetic rates with increasing tree age and size in Picea abies and Pinus sylvestris. Tree Physiol. 22: 515-535.

Niinemets Ü., 2006. The controversy over traits conferring shadetolerance in trees: ontogenetic changes revisited. J. Ecol. 94: 464470 .

Niinemets Ü. and Kull O., 1998. Stoichiometry of foliar carbon constituents varies along light gradients in temperate woody canopies: implications for foliage morphological plasticity. Tree Physiol. 18: 467-479.

Poorter L., 1999. Growth responses of 15 rain-forest tree species to a light gradient: the relative importance of morphological and physiological traits. Funct. Ecol. 13: 396-410.

Poorter L., Oberbauer S.F., and Clark D.B., 1995. Leaf optical properties along a vertical gradient in a tropical rain forest canopy in Costa Rica. Am. J. Bot. 82: 1257-1263.

Poorter L., Bongers L., and Bongers F., 2006. Architecture of 54 moistforest tree species: Traits, trade-offs, and functional groups. Ecology 87: $1289-1301$

Popma J., Bongers F., and Werger M.J.A., 1992. Gap-dependence and leaf characteristics of trees in a tropical lowland rain forest in Mexico. Oikos 63: 207-214. 
Rijkers T., Pons T.L., and Bongers F., 2000. The effect of tree height and light availability on photosynthetic leaf traits of four neotropical species differing in shade tolerance. Funct. Ecol. 14: 77-86.

Roggy J.-C., Nicolini E., Imbert P., Caraglio Y., Bosc A., and Heuret P., 2005. Links between tree structure and functional leaf traits in the tropical forest tree Dicorynia guianensis Amshoff (Caesalpiniaceae). Ann. For. Sci. 62: 553-564.

Rozendaal D.M.A., Hurtado V.H., and Poorter L., 2006. Plasticity in leaf traits of 38 tropical tree species in response to light; relationships with light demand and adult stature. Funct. Ecol. 20: 207-216.

Sterck F.J. and Bongers F., 1998. Ontogenetic changes in size, allometry, and mechanical design of tropical rain forest trees. Am. J. Bot. 85: 266-272.

Thomas S.C. and Winner W.E., 2002. Photosynthetic differences between saplings and adult trees: an integration of field results by metaanalysis. Tree Physiol. 22: 117-127.
Valladares F. and Niinemets U., 2008. Shade tolerance, a key plant feature of complex nature and consequences. Annu. Rev. Ecol. Evol. Syst. 39: 237-57.

Valladares F., Wright S.J., Lasso E., Kitajima K., and Pearcy R.W., 2000. Plastic phenotypic response to light of 16 congeneric shrubs from a Panamanian rainforest. Ecology 81: 1925-1936.

Veneklaas E.J. and Poorter L., 1988. Growth and carbon partitioning of tropical tree seedlings in contrasting light environments. In: H. Lambers, H. Poorter and M. Van Vuuren (Eds.), Inherent variation in plant growth: physiological mechanisms and ecological consequences, Backhuys publishers, Leiden, The Netherlands, pp. 337-355.

Warren C.R., 2006. Estimating the internal conductance to $\mathrm{CO}_{2}$ movement. Funct. Plant Biol. 33: 431-442.

Wright S.D. and McConnaughay K.D.M., 2002. Interpreting phenotypic plasticity: the importance of ontogeny. Plant Species Biol. 17: 119-131. 